\title{
S100A2 wt Allele
}

National Cancer Institute

\section{Source}

National Cancer Institute. S100A2 wt Allele. NCI Thesaurus. Code C52260.

Human S100A2 wild-type allele is located within $1 \mathrm{q} 21$ and is approximately $5 \mathrm{~kb}$ in length.

This allele, which encodes S100-A2 protein, plays a role in the regulation of several diverse cellular processes including cell cycle progression and differentiation.

Chromosomal rearrangements and altered gene expression have been implicated in breast cancer. 